\title{
Induction of Root Browning by Chloramine in Lactuca sativa L. Grown in Hydroponics
}

\author{
Shuichi Date ${ }^{1 *}$, Satoshi Terabayashi ${ }^{1}$, Kouhei Matsui ${ }^{1}$, Takakazu Namiki ${ }^{2}$ and Yukihiro Fujime ${ }^{1}$ \\ ${ }^{1}$ Faculty of Agriculture, Kyoto Prefectural University, Shimogamo, Sakyo - ku, Kyoto 606-8522 \\ ${ }^{2}$ Kyoto Prefectural Institute of Agricultural Biotechnology, Souraku - gun, Kyoto 619-0244
}

\begin{abstract}
Summary
The cause of root browning (RB) in Lactuca sativa $\mathrm{L}$. root, which often occurs in hydroponics when a nutrient solution is prepared with tap water, was investigated. The induction of RB occurred only when plants were cultured in the solutions containing both hypochlorous acid $(\mathrm{HOCl})$ and ammonium ion $\left(\mathrm{NH}_{4}{ }^{+}\right)$, but not in the solutions contained either $\mathrm{HOCl}$ or $\mathrm{NH}_{4}{ }^{+}$alone. The addition of $\mathrm{NaOCl}(\mathrm{HOCl})$ followed by $\mathrm{NH}_{4} \mathrm{H}_{2} \mathrm{PO}_{4}\left(\mathrm{NH}_{4}{ }^{+}\right)$solution after a 7-10 day storage or $\mathrm{NH}_{4} \mathrm{H}_{2} \mathrm{PO}_{4}$ followed by $\mathrm{NaOCl}$ solution induced no $\mathrm{RB}$ symptom. It was concluded that $\mathrm{RB}$ was induced by chloramine, a reaction product between $\mathrm{HOCl}$ and $\mathrm{NH}_{4}{ }^{+}$. Dechlorination of nutrient solutions was promoted in the presence of the iron ion in the solution under light conditions.
\end{abstract}

Key Words: chloramine, $\mathrm{HOCl}$, Lactuca sativa $\mathrm{L}$., $\mathrm{NH}_{4}{ }^{+}$, root browning.

\section{Introduction}

The occurrence of root browning (RB) in Lactuca sativa $\mathrm{L}$. roots, an abnormal discoloration of the epidermis, has been frequently associated with hydroponic culture. This physiological disorder is often induced when a nutrient solution is renewed to prevent plant disease or to modify the balance of nutrient elements. Such RB develops within a few hours and causes the plants to wilt, leads to growth inhibition, or even death.

Krone and Weinard (1931), Zimmermann and Berg (1934), Buxton (1938), Bridgen (1986), and Frink and Bugbee (1987) reported that residual chlorine in the form of hypochlorous acid ( $\mathrm{HOCl}$ ) in tap water at near neutral $\mathrm{pH}$ induced $\mathrm{RB}$ and inhibited root and plant growth, but the critical concentrations of $\mathrm{HOCl}$ differed among the reports. It has been reported that $\mathrm{NH}_{4}{ }^{+}$at 6 to $15 \mathrm{me} \cdot$ liter $^{-1}$ in hydroponic culture causes RB (Maynard and Barker, 1969; Ikeda and Osawa, 1982; Findenegg, 1987) but not at less than $2 \mathrm{me} \cdot$ liter $^{-1}$ generally present in nutrient solution.

In this paper, we examined why hydroponic culture causes the development of RB, and found that it occurred when chloramine, a reaction product between $\mathrm{HOCl}$ in tap water and $\mathrm{NH}_{4}^{+}$, in the nutrient solution reaches a toxic level.

\section{Materials and Methods}

\section{Exp. 1. Identification of $\mathrm{HOCl}$ and $\mathrm{NH}_{4}^{+}$as causal elements for the occurrence of $R B$}

Butter head lettuce (Lactuca sativa L.) cv. Okayamasaradana seeds, which were sown in commercial soil on July 3, 1999 and watered, were transferred to the halfstrength of Enshi standard nutrient solution (HENS) at the 3-leaf stage. The concentrations of $\mathrm{NO}_{3}-\mathrm{N}, \mathrm{NH}_{4}-$ $\mathrm{N}, \mathrm{P}, \mathrm{K}, \mathrm{Ca}$ and $\mathrm{Mg}$ as macro elements in the HENS were $8,0.67,2,4,4$ and $2 \mathrm{me} \cdot \operatorname{liter}^{-1}$, respectively. Whereas $\mathrm{Fe}, \mathrm{B}, \mathrm{Mn}, \mathrm{Cu}, \mathrm{Zn}$ and $\mathrm{Mo}$ as micro elements were $3,0.5,0.5,0.02,0.05$ and $0.01 \mathrm{mg} \cdot \operatorname{liter}^{-1}$, respectively. The $\mathrm{pH}$ of HENS, prepared with tap water in experimental field of Kyoto Prefectural University, was 6.2. Five seedlings were fixed on a styrofoam plate $(100$ $\times 400 \times 20 \mathrm{~mm})$ with a urethane cube $(25 \times 25 \times 30$ $\mathrm{mm})$. Seven styrofoam plates were floated on 40 liters of the above mentioned nutrient solution, in a plastic container $(440 \times 740 \times 240 \mathrm{~mm})$. At the 12 - leaf stage, 6 seedlings were fixed on another styrofoam plate (300 $\times 400 \times 25 \mathrm{~mm}$ ), and the plate was floated on 20 liters of each test solution in a plastic container $(320 \times 420 \times$ $215 \mathrm{~mm}$ ). Treatments were duplicated. The nutrient solution was aerated continuously with an air pump, and the $\mathrm{pH}$ of nutrient solutions was not regulated.

In Exp. 1.1, to determine which nutrient element causes RB, seedlings were transplanted to the HENS without one of following elements ; $\mathrm{Ca}\left(\mathrm{NO}_{3}\right)_{2}, \mathrm{KNO}_{3}$, $\mathrm{MgSO}_{4}, \mathrm{NH}_{4} \mathrm{H}_{2} \mathrm{PO}_{4}, \mathrm{NaFe}$-EDTA, and the other micro elements, prepared with tap water. In Exp. 1.2, plants were cultured in tap water with $\mathrm{NaH}_{2} \mathrm{PO}_{4}$ or $\left(\mathrm{NH}_{4}\right)_{2} \mathrm{SO}_{4}$ at concentrations equivalent to those in HENS. In Exp. 
10-day storage. Neutral tap water contains residual chlorine as $\mathrm{HOCl}$ that decomposes with time (Kaneko, 1996), which indicates that $\mathrm{HOCl}$ might be involved in RB. In Exp. 1.4, RB did not occur in the solution containing only $\mathrm{NaOCl}$ (Table 3), but $\mathrm{NaOCl}$ in approximately $\mathrm{pH}$ neutral water hydrolyzes to $\mathrm{HOCl}$. Frink and Bugbee (1987) found that the growth of the most susceptible species among eight different potted plants and four different vegetables was significantly decreased when they were irrigated with the water containing $2 \mathrm{mg}$ $\mathrm{Cl} \cdot \operatorname{liter}^{-1} \mathrm{HOCl}$, but not with that containing $1 \mathrm{mg} \mathrm{Cl}$. liter $^{-1} \mathrm{HOCl}$. Zimmermann and Berg (1934) reported that less than $5 \mathrm{mg} \mathrm{Cl} \cdot \operatorname{liter}^{-1} \mathrm{HOCl}$ had no effect on plant growth in most of the 13 species they examined. In our nutrient solution in this experiment $\mathrm{HOCl}$ was only equivalent to $0.5 \mathrm{mg} \mathrm{Cl} \cdot$ liter $^{-1}$, much less than that in the above reports, so that $\mathrm{RB}$ is not induced by $\mathrm{HOCl}$.

In Exp. 1.4, intensive RB was observed in the solution containing both $\mathrm{NaOCl}$ and $\left(\mathrm{NH}_{4}\right)_{2} \mathrm{SO}_{4}$ (Table 3). The

Table 3. Occurrence of RB in lettuce cultured in deionized water with containing $\mathrm{NH}_{4}{ }^{+}$and/or $\mathrm{HOCl}$ added.

\begin{tabular}{lc}
\hline \multicolumn{1}{c}{ Solution } & Brown symptom in root $^{2}$ \\
\hline Deionized water & - \\
$\left(\mathrm{NH}_{4}\right) \mathrm{SO}_{4}$ & - \\
$\mathrm{NaOCl}$ & - \\
$\left(\mathrm{NH}_{4}\right)_{2} \mathrm{SO}_{4}+\mathrm{NaOCl}$ & + \\
\hline
\end{tabular}

${ }^{\mathrm{z}}$ See Table 1. symptom and progress of RB were the same as in Exp. 1.1 and 1.2. This result strongly suggests that $R B$ occurs when $\mathrm{HOCl}$ and $\mathrm{NH}_{4}{ }^{+}$coexist in nutrient solution that react to form chloramine (Kaneko 1996). In Exp. 2, the presence of both $\mathrm{NaOCl}$ and $\mathrm{NH}_{4} \mathrm{H}_{2} \mathrm{PO}_{4}$, induced $\mathrm{RB}$ and wilting in all plants (treatment 2 in Table 4 and Fig. 1). Plants, exposed to $\mathrm{NaOCl}$, did not develop $\mathrm{RB}$ and wilt although the roots lost turgor (treatments 3,5 and 6 in Table 4 and Fig. 2), which suggested that $0.5 \mathrm{mg} \mathrm{Cl}$. liter $^{-1}$, equivalence of $\mathrm{HOCl}$, is slightly harmful to lettuce roots. It also suggests that the serious $\mathrm{RB}$ might be caused by chloramine, but not by $\mathrm{HOCl}$ or $\mathrm{NH}_{4}{ }^{+}$. Chloramine is known to change its form depending on the $\mathrm{pH}$ and chlorine: $\mathrm{NH}_{4}{ }^{+}$ratio, e.g. mono-chloramine $\left(\mathrm{NH}_{2} \mathrm{Cl}\right)$, di-chloramine $\left(\mathrm{NHCl}_{2}\right)$ and nitrogen trichloride $\left(\mathrm{NCl}_{3}\right)$. Since HENS is prepared with tap water in the experimental farm of Kyoto Prefectural University,

Table 4. Occurrence of RB in lettuce alternately treated with $\mathrm{HOCl}$ and/or $\mathrm{NH}_{4}{ }^{+}$.

\begin{tabular}{lc}
\hline \multicolumn{1}{c}{ Treatment } & Brown symptom in root \\
\hline 1. Dechlorinated tap water & - \\
2. $\mathrm{NaOCl}+\mathrm{NH}_{4} \mathrm{H}_{2} \mathrm{PO}_{4}$ & + \\
3. $\mathrm{NaOCl}$ & - \\
4. $\mathrm{NH}_{4} \mathrm{H}_{2} \mathrm{PO}_{4}$ & - \\
5. $24-\mathrm{hr} \mathrm{NaOCl} \rightarrow \mathrm{NH}_{4} \mathrm{H}_{2} \mathrm{PO}_{4}$ & - \\
6. $24-\mathrm{hr} \mathrm{NH} \mathrm{NH}_{2} \mathrm{PO}_{4} \rightarrow \mathrm{NaOCl}$ & - \\
\hline
\end{tabular}

${ }^{2}$ See Table 1.

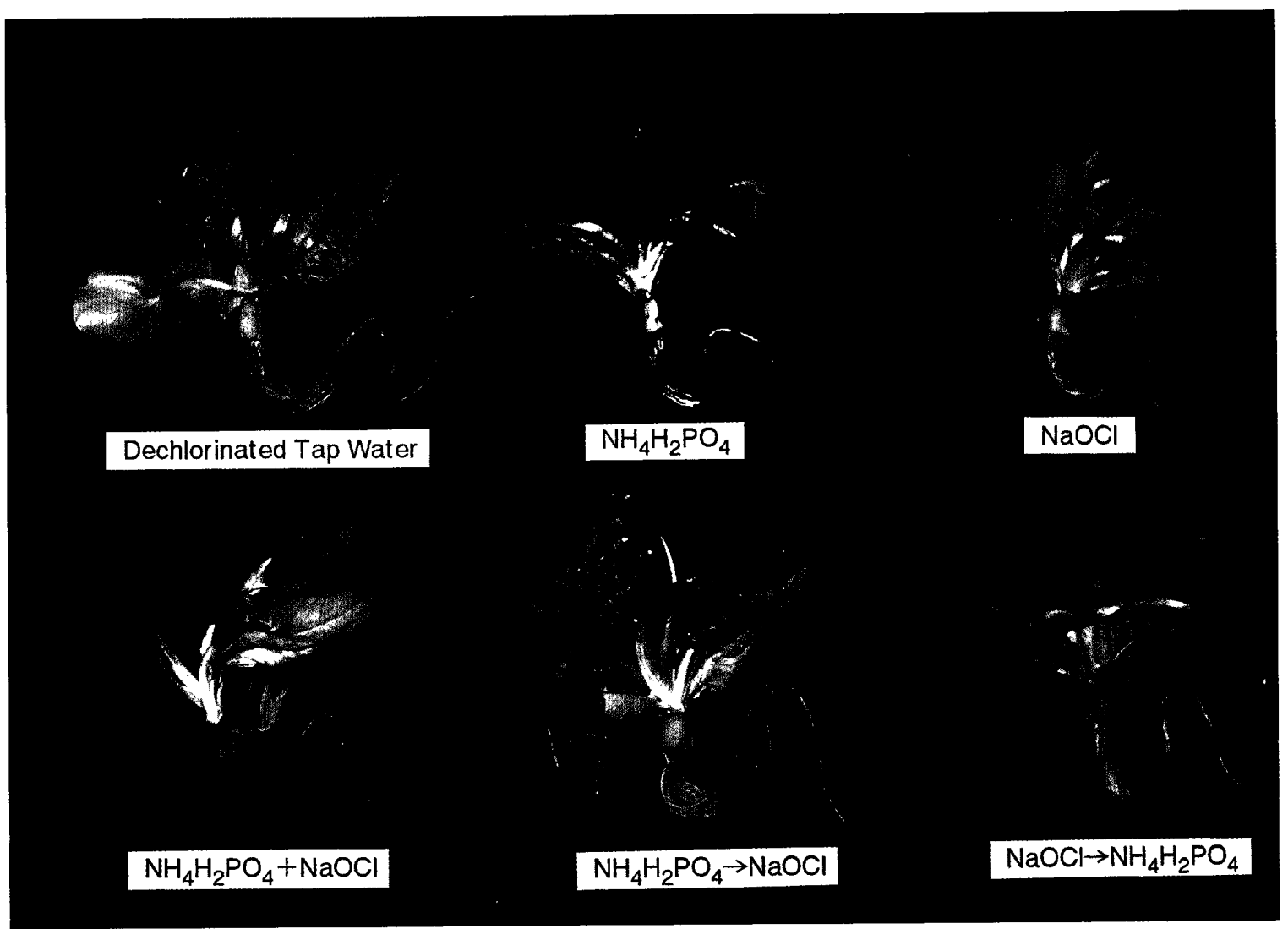

Fig. 1. Lettuce plants 4 days after alt..nate treatment with $\mathrm{HOCl}$ and/or $\mathrm{NH}_{4}{ }^{+}$(Exp. 2). 
$\mathrm{pH}$ is approximately neutral and chlorine: $\mathrm{NH}_{4}{ }^{+}$ratio is approximately $1: 24$. Hence, the dominant chloramine in the present experiment is considered to be $\mathrm{NH}_{2} \mathrm{Cl}$ (Kaneko, 1996).

Generally, in the water filtration plant, tap water is prepared by adding $\mathrm{Cl}_{2}$, which form $\mathrm{HOCl}$ in neutral $\mathrm{pH}$ water, to suppress the propagation of harmful microorganisms. Iron and organic matter are known to promote the decomposition of $\mathrm{HOCl}$ (Yamada, 1987). Light, especially ultra violet light, breaks down $\mathrm{NaFe}^{-}$ EDTA in the nutrient solution into iron ions and organic
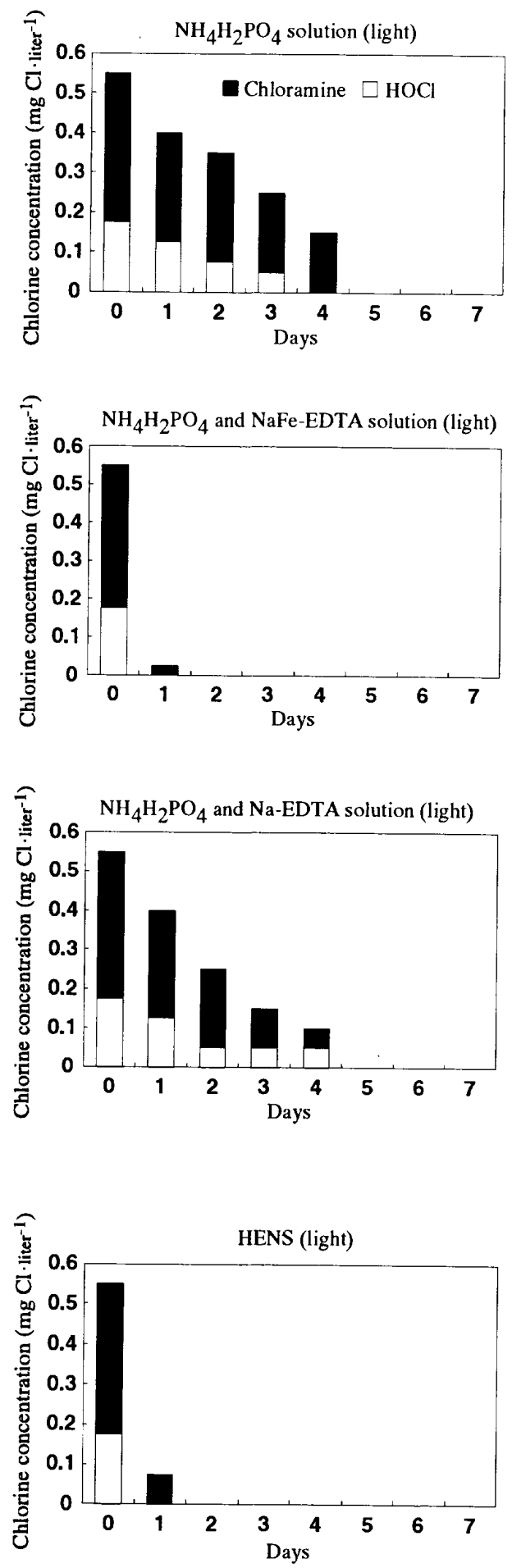

compounds. However, the equilibrium between $\mathrm{HOCl}$ and chloramine in the nutrient solution prepared with tap water is not known. In Exp. 3, the concentrations of $\mathrm{HOCl}$ and chloramine in the nutrient solution, containing many nutrient elements, change with time in the light and dark. At the start of the treatments, the concentration of total chlorine in all solution was $0.5 \mathrm{mg}$ $\mathrm{Cl} \cdot \operatorname{liter}^{-1}$ (Fig. 2) while that of chloramine in the nutrient solutions containing both $\mathrm{HOCl}$ and $\mathrm{NH}_{4}{ }^{+}$was $0.3 \mathrm{mg} \mathrm{Cl} \cdot$ liter $^{-1}$ at day 0 . In the light, total chlorine in the solutions containing NaFe-EDTA decreased to zero
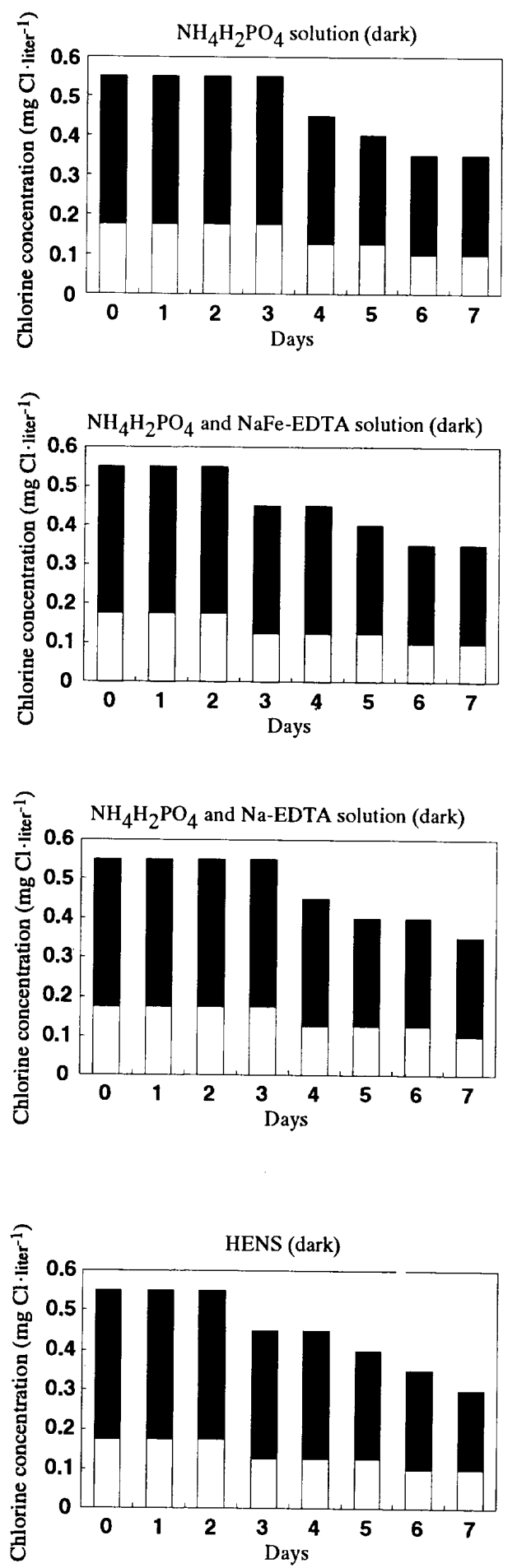

Fig. 2. Changes in the concentrations of chloramine and $\mathrm{HOCl}$ in $\mathrm{NH}_{4} \mathrm{H}_{2} \mathrm{PO}_{4}$ solutions containing either $\mathrm{NaFe}^{-}$ EDTA or Na-EDTA and in HENS prepared with tap water in the light and darkness. Almost same results were obtained in three independent experiments. Typical data are shown here. 
on day 2 but it was day 5 in the absence of $\mathrm{NaFe}$ EDTA. In the dark, disappearance of total chlorine was slow, the concentration remained higher than $0.3 \mathrm{mg} \mathrm{Cl}$. liter $^{-1}$ even at day 7. These results show that the residual chlorine decreases faster in the light than in the dark, especially in the presence of $\mathrm{NaFe}$-EDTA. Additional tests revealed that it was the iron ion rather than EDTA that caused the reduction of total chlorine in the light.

In this study, we concluded that chloramine induces the root injury in the lettuce plant. In Japan, 34\% of hydroponic growers use tap water, $63 \%$ underground water and $6 \%$ rain water, according to the Research Data of National Institute of Vegetable, Ornamental and Tea No. 21 (1986). The use of chlorinated tap water prevents the spread of plant pathogens and pollution of underground water with nitrate and other nutrient elements. Tap water may contain more than $1 \mathrm{mg} \mathrm{Cl} \cdot \operatorname{liter}^{-1}$, depending on the season and distance from the water filtration plant to the greenhouse. In addition, growers often treat the irrigation systems, seeds, and seedlings with $\mathrm{HOCl}$ to sterilize them; this results in the formation of chloramine and root injury. It is clear that chlorine compounds decompose in the light, especially in the presence of iron ion. But nutrient solutions are often kept in the dark so that chlorine compounds are not expected to decompose rapidly. Furthermore, iron ion forms iron hydroxide easily and cannot be absorbed by the plant. Thus, it may be necessary to dechlorinate the nutrient solution with a reducing agent such as sodium thiosulfate (Yamazaki, 1982), although the effect of reducing agents on plants is still unknown.

\section{Literature Cited}

Bridgen, M. P. 1986. Good for you, bad for your crops. Greenhouse Grower 4: 58-59.

Buxton, B. R. 1938. Chlorinated water fatal to plant. Horticulture 16: 422.

Findenegg, G. R. 1987. A comparative study of ammonium toxicity at different constant $\mathrm{pH}$ of the nutrient solution. Plant Soil. 103: 239-243.

Frink, C. R. and G. J. Bugbee. 1987. Response of potted plants and vegetable seedlings to chlorinated water. HortScience 22: 581-583.

Ikeda, H. and T. Osawa. 1982. Effect of potassium and calcium levels and their accompanying anions in the nutrient solution on ammonium toxicity in vegetable crops. J. Japan. Soc. Hort. Sci. 51: 309-317.

Kaneko, M. 1996. Sterilization by Chlorine. p. 282-312 In: M. Kaneko (eds.). Water sanitary science. Gihoudoushuppan, Tokyo (In Japanese).

Krone, W. J. and F. F. Weinard. 1931. Experiments with solutions of chlorine and sodium chloride on pot plants. Proc. Amer. Soc. Hort. Sci. 27: 444- 448.

Maynard D. N. and A. V. Barker. 1969. Studies on the tolerance of plants to ammonium nutrition. J. Amer. Soc. Hort. Sci. 94: 235- 239.

Yamada, J. 1987. Remove of Iron and Munganese. p. 145. In: T. Sueishi (eds.). Sanitary engineering. Kashimashuppankai, Tokyo (In Japanese).

Yamazaki, K. 1982. Water material. p. 93-97. In The Whole of Hydroponics. Hakuyusha, Tokyo (In Japanese).

Zimmermann, P. W. and R. O. Berg. 1934. Effects of chlorinated water on the land plants and gold fish. Contrib. Boyce Thompson Inst. 6: 39-49.

\author{
水耕栽培におけるクロラミンにより発生するサラダナの根部褐変 \\ 伊達修一 ${ }^{1} \cdot$ 寺林 $^{\text {敏 }^{1}} \cdot$ 松井浩平 $^{1} \cdot$ 並木隆和 $^{2} \cdot$ 藤目幸撗 $^{1}$ \\ ${ }^{1}$ 京都府立大学農学部 606-8522 京都市左京区下鴨半木町 1-5 \\ 2 京都府農業資源研究センター 619-0244 京都府相楽郡精華町
}

水道水を用いて作成した培養液による水耕栽培で，しばし ば発生する根部褐変の原因について調査した。サラダナの根 部褐変は次亜塩素酸の形態で存在する水道水中の残留塩素と アンモニウムイオンが存在する培着液でのみ発生し, どちら か一方しか存在しない培羡液では発生しなかった，また，次 亚塩素酸あるいはアンモニウムイオンどちらかを含む培養液
に交互に移植しても根部褐変は発生しなかった，従って，根 部褐変は次亜塩素酸とアンモニウムイオンにより生成するク ロラミンにより発生するものと考えられた，さらに培養液中 の残留塩素濃度の低下は, 光条件下で鉄イオンの存在により 促進された。 